\title{
A review of potential impacts of submarine power cables on the marine environment: Knowledge gaps, recommendations and future directions
}

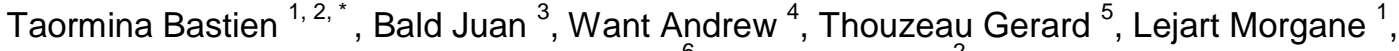 \\ Desroy Nicolas ${ }^{6}$, Carlier Antoine ${ }^{2}$
}

${ }^{1}$ France Energies Marines, Technopôle Brest Iroise, 15 rue Johannes Kepler, 29200 Brest, France

${ }^{2}$ Ifremer, Centre de Bretagne, DYNECO - Laboratoire d'écologie benthique, ZI de la Pointe du Diable CS 10070, 29280 Plouzané, France

${ }^{3}$ Marine Research Division, AZTI-Tecnalia, Muelle de la Herrera, s/n, 20110 Pasajes, Gipuzkoa, Spain

${ }^{4}$ International Centre for Island Technology - Heriot-Watt University, Stromness, Orkney, United

Kingdom

${ }^{5}$ CNRS-UBO, IUEM, UMR 6539 - LEMAR, Technopôle Brest-Iroise, 4 rue Dumont d'Urville, 29280

Plouzané, France

${ }^{6}$ Ifremer, Laboratoire Environnement Ressources Bretagne Nord, 38 rue du Port Blanc, 35801 Dinard, France

${ }^{*}$ Corresponding author : Bastien Taormina, email address :

bastien.taormina@france-energies-marines.org

\begin{abstract}
:
Submarine power cables (SPC) have been in use since the mid-19th century, but environmental concerns about them are much more recent. With the development of marine renewable energy technologies, it is vital to understand their potential impacts. The commissioning of SPC may temporarily or permanently impact the marine environment through habitat damage or loss, noise, chemical pollution, heat and electromagnetic field emissions, risk of entanglement, introduction of artificial substrates, and the creation of reserve effects. While growing numbers of scientific publications focus on impacts of the marine energy harnessing devices, data on impacts of associated power connections such as SPC are scarce and knowledge gaps persist. The present study (1) examines the different categories of potential ecological effects of SPC during installation, operation and decommissioning phases and hierarchizes these types of interactions according to their ecological relevance and existing scientific knowledge, (2) identifies the main knowledge gaps and needs for research, and (3) sets recommendations for better monitoring and mitigation of the most significant impacts. Overall, ecological impacts associated with SPC can be considered weak or moderate, although many uncertainties remain, particularly concerning electromagnetic effects.
\end{abstract}




\section{Graphical abstract}

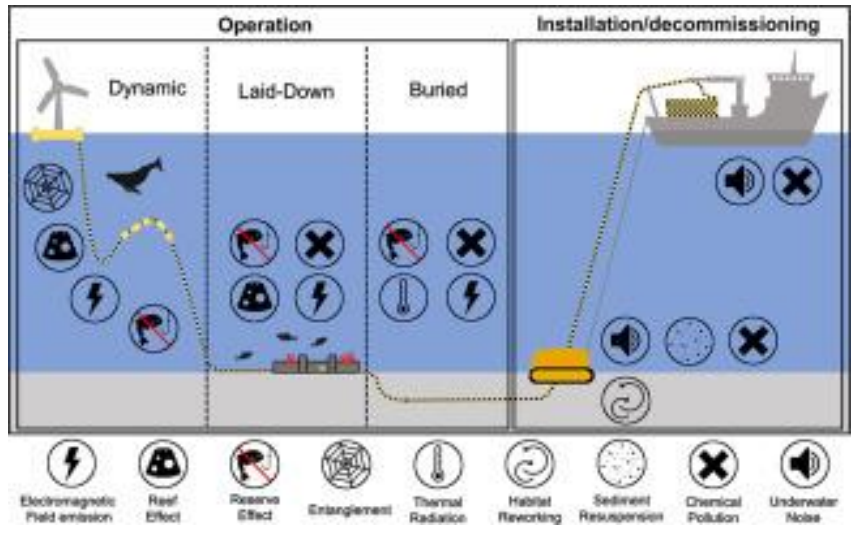

\section{Highlights}

The use of submarine power cables will increase due to the growth of the marine renewable energy sector. Installation increases noise, pollution, turbidity and physical disturbance. Operation produces electromagnetic fields, heat, entanglement risk, pollution and reef/reserve effects. $>$ Overall impacts on ecosystems are considered minor or short-term. Uncertainties remain, particularly concerning the impacts of electromagnetic fields.

\section{Abbreviations}

HVD CHigh-Voltage Direct Current

SPC Submarine Power Cable

DC Direct Current

AC Alternating Current

MRE Marine Renewable Energy

SPL Sound Pressure Level

HVAC High Voltage Alternating Current

EMF Electromagnetic Field

Keywords : Submarine power cables, Marine renewable energy, Environmental impacts, Ecosystem functioning, Benthic habitats 


\section{Introduction}

In 1811, a powered cable was laid down across the Isar River in Germany. This is considered to be the first underwater power cable in the world. More than a century later, the first commercial High Voltage

Direct Current (HVDC) cable, installed in 1954 in the Baltic Sea, linking Sweden and Gotland Island.

5 Since then, submarine power cables (SPC), using direct current (DC) or alternating current (AC), have

6 continued to spread across the globe. Technologies have improved with respect to materials, cable length

7 and width, and installation techniques. Applications of SPC are numerous: they can be used to connect

8 autonomous grids, to supply power to islands, marine platforms or subsea observatories, and to convey

9. power generated by marine renewable energy (MRE) installations to electrical sub-stations. While most SPC are on top of or buried within the seafloor, some (known as dynamic cables) are deployed through the water column between the surface and the seafloor. This last category of cables is used for offshore oil platforms and, recently, to export energy produced by floating MRE devices (like wind turbines), a technology still under development. In 2015, almost $8000 \mathrm{~km}$ of HVDC were present on the seabed worldwide, $70 \%$ of which were in European waters. In comparison, the total length of all submarine cables deployed (including AC and DC power cables and telecommunication cables) is of the order of $10^{6} \mathrm{~km}$ [1].

SPC, like any other man-made installation or human activity at sea, may cause disturbances to marine life and habitats. When talking about anthropogenic disturbances, it is important to distinguish 'effects' from 'impacts'. According to the framework proposed by Boehlert and Gill [2], effects are modifications of environmental parameters (or "stressors"), such as the substrate type, hydrodynamics, water temperature, noise, or electromagnetic fields beyond the range of natural variability. Impacts correspond to changes observed at "receptor" level, i.e., the different ecosystem compartments (biotopes, biocenosis), or levels (community, populations) or some ecological processes within marine ecosystems (trophic interactions). Impacts may be positive or negative, although this distinction remains subjective.

Scientific interest in interactions between marine life and submarine cables started with the first records of cable damage caused by whale entanglements (16 events between 1877 and 1955; [3]) or by fish and shark bites (at least 39 events from 1907 to 2006; [4]). Although such events have decreased significantly with technological improvements (cable burial and advances in design or protection; [5]), ecological concerns remain. Nowadays, ecological issues refer not only to direct physical interactions 
between large animals and cables but also to less obvious impacts of cables on marine communities and habitats.

Numbers of SPC will increase drastically in coming decades with increasing grid connections of islands and archipelagos and the development of MRE projects (offshore wind farms, tidal and wave turbines). Several inter-governmental organisations have set objectives for the next decades. For example, in 2014, the European Council set $27 \%$ as a target for the minimum proportion of total electricity consumption produced by renewable energies in the EU by 2030 (EUCO 169/14). In 2008, the global electric energy supply produced by all grid-connected renewable energy installations taken together was estimated at $12.9 \%$, and several predictions estimate an increase to $17 \%$ by 2030 and $27 \%$ by 2050 [6].

Despite more than 10 years of scientific work on potential environmental impacts of MRE projects [7,8], SPC have received much less attention than MRE devices themselves. Indeed, only nine published papers focusing on in situ effects or impacts of SPC were found during the literature research. These studies addressed the impacts of SPC on benthic communities, considering both installation or operation phases [9-13], examined communities colonising unburied structures [12,14], and/or reported species-specific changes of behaviour [15-17]. Considering the current exponential increase in SPC worldwide, a robust and accurate assessment of their potential environmental impacts has become a priority.

In this context, the aims of the present study are (1) to review the existing knowledge concerning potential ecological impacts from SPC during installation, operation and decommissioning phases, (2) to attempt to hierarchize these impacts according to their significance and (3) to point out knowledge gaps and recommendations for monitoring and mitigation of these impacts.

\section{Methods}

A literature search was conducted using online databases and internet search tools (Web of Science, Science Direct, Google Scholar, ResearchGate) to create a bibliographic database including peer-reviewed scientific publications, books, theses and non-peer-reviewed consultancy and technical reports. Owing to a general lack of published studies, a large proportion of current knowledge comes from industrial or governmental reports and environmental impact assessments that may have associated confidentiality issues. The literature search first focused on publications about SPC generalities and their global environmental impacts before targeting specific literature for each of the different identified impacts. 
Documents focussing on anthropogenic disturbances other than SPC, but potentially inducing comparable impacts (e.g., artificial reefs or sediment reworking for example) were also considered. Based on the main conclusions of the reviewed literature, the relative importance of the different potential impacts and the associated scientific uncertainty was compiled.

\section{Features of submarine power cables}

\subsection{Technical characteristics}

SPC are specifically designed to relay electric currents either as Alternating Current (AC) or Direct Current (DC), the transmission type being determined by the capacity and length of the transmission line, as well as commercial issues. For example, a DC line can transmit more power than an AC line of the same size, but is more expensive. AC transmission presents some limitations since the reactive power flow due to the large cable capacitance causes power loss, which then limits the maximum transmission distance $(<100 \mathrm{~km})$. DC is therefore the only viable technical option for long distance cable links. AC is more frequently used within grids of marine renewable energy devices [8]. Cables in use today include monopolar, bipolar and three-phase systems. SPC diameters are between 5 and $30 \mathrm{~cm}$ and weigh between 15 and $120 \mathrm{~kg} \mathrm{~m}^{-1}$ (including stabilization devices such as articulated steel shell). Different methods exist to insulate electric cables in order to contain the emitted electric fields. Specific designs have been addressed for dynamic cables, with specific armouring layers and internal components. Indeed, their high position in the water column makes them more susceptible to fatiguing pressure and twist caused by hydrodynamics (particularly swell). Table 1 describes most types of recently installed SPC.

\subsection{Cable installation}

Before any deployment, the cable route must be chosen, depending on the bathymetry, seabed characteristics and economic activities of an area. The route must first be prepared, sometimes with adjustment of the slope and depth, or removal of obstacles before the passage of the cable-laying device. An example of an established method is the pre-lay grapnel run, consisting of dragging a hooking device at low speed along the planned route to remove any material, such as abandoned ropes or fishing nets.

Cable deployment is a complex process requiring highly specialised equipment. Cables are usually buried within the seafloor by different techniques including trenching with a cutting wheel in rocky sediments and ploughing or water jetting in soft sediments (Figure 1; [18]). Ploughing generally allows 
trenching, laying the cable and burying it with the extracted sediment in a single operation. Special backfill materials for burial can be required when burial is technically complicated. In the case of hard or deep bottoms, the cable can simply be laid on the seafloor and stabilised with suitable cover. The duration of the cable installation process determines the magnitude of some environmental effects, such as increased turbidity or anthropogenic noise. The duration of installation can be highly variable according to methods and seafloor characteristics, as cable laying is much more difficult for a route with obstacles such as boulders, rocks or outcrops, compared with a featureless seafloor [18]. The rate of cable-laying may vary from $0.13-0.21 \mathrm{~km} \mathrm{~h}^{-1}$ for a cable buried using water jetting to $1.85 \mathrm{~km} \mathrm{~h}^{-1}$ for a cable that is simply laid down [19]. For cable burial in the upper intertidal zone, the trench is often dug with more common devices such as mechanical excavators, and directional drilling is sometimes employed.

\subsection{Cable protection}

Depending on anthropogenic and natural perturbations in the route area, the cables may need to be protected from damage caused by fishing gear or anchors [19], strong hydrodynamic forces or storms. When trenching is not possible, other methods exist for unburied cables, such as rock-mattress covering, cable anchoring, ducting, cast-iron shells, concrete slabs, steel plates or dumped rocks [19]. On uneven seafloors, the cable may form "free spans" along its route where it will hang without touching the seafloor. This may promote vibration, chafing, fatigue and, ultimately, cable failure [18]. One solution is to fill the empty space between the cable and the seafloor with rock dumping or concrete bags. As an example of protection methods employed, the cable connecting the French tidal turbine test site of Paimpol-Bréhat to the land was installed on a highly hydrodynamic and hard seafloor (rock and pebbles). The cable is unburied over a large portion of its route but is protected with cast-iron shells and concrete mattresses (Figure 2); the free spans are filled with concrete bags. In addition to these different protection methods, authorities typically create a protected area encompassing the cable route, with prohibition of other human activities (fishing, anchoring, dredging, etc.) in order to protect the cable from damage.

\section{Environmental effects and impacts}

Potential environmental effects associated with SPC are summarised in Figure 3. During installation, maintenance and decommissioning phases, these effects may include physical habitat disturbances, sediment resuspension, chemical pollution and underwater noise emission. More long-term effects may 
occur during the operational phase, with changes in electromagnetic fields, heat emission, risk of entanglement, chemical pollution, and creation of artificial reef and reserve effects.

\subsection{Habitat reworking}

\section{- Physical changes}

Substratum alterations are mainly created by equipment used for cable route preparation (grapnels such as in the aforementioned Pre-Lay Grapnel Run) and installation of the cable (ploughing, jetting and cuttingwheels). The surface area of disturbance can be enlarged when installation techniques require large ships with several anchoring stabilizers [18].

These methods of reworking the seabed may lead to direct destruction of benthic habitats, flora and fauna. However, such effects are usually restricted to a limited area, the width and intensity of disturbance, depending on the installation method. For example, the footprint of a trenching plough may vary from 2 to $8 \mathrm{~m}$ depending on device size [5]. According to Vize et al. [20], ploughing methods seem to cause less seabed disturbance than other methods. These disturbances are usually limited in time, as installation works only require a few hours or days per $\mathrm{km}$ of cable [21]. Ploughing and jetting methods favour a quicker recovery of bottom topography, as the trench is filled with displaced and re-suspended material immediately after digging and cable laying. In intertidal areas, physical impacts on the substrate usually occur over a larger surface area, of the order of tens of metres, due to the utilisation of vehicles such as mechanical excavators (Figure 4). Alternatively, underground horizontal directional drilling (10 m below the sediment surface) may be used in intertidal areas up to distances of $700-1000 \mathrm{~m}$, and occasionally up to $1800 \mathrm{~m}$ [18]. This installation technique only disturbs the substrate and biota locally over a few $\mathrm{m}^{2}$ at the land and sea entrance points.

Unburied cables may also cause habitat loss, but to a lesser extent than buried cables. Disturbance is limited to the cable width itself, or to the dimensions of the materials used to stabilise and protect [22]. In shallow areas, some sections of unstabilised, unburied cables may act as dragging elements that disturb the sediments due to their strumming movement induced by the swell during the operation phase [23]. Wave action may shift the cable, and direct interaction with the hard seafloor can result in surface scraping and incisions in rock outcrops [13]. Maintenance (to a lesser extent) and/or decommissioning phases may generate similar effects to those of installation, but their magnitude will depend on the duration and scale (repairs vs. inspections) of the works. 
With respect to other human activities at sea, physical disturbance to the seabed caused by cables is spatially limited. For example, the footprint of submarine cables in the UK coastal area is about $0.3 \mathrm{~km}^{2}$, representing less than $0.01 \%$ of the coastal seabed [24], whilst in the Basque Country coastal zone (Northern Spain), the footprint of cables and pipelines is about $2.3 \mathrm{~km}^{2}$, or $0.02 \%$ of the area between the coastline and the exclusive economic zone [25].

\section{- Biological changes}

Substratum alterations may affect related benthic communities by direct impacts such as displacement, damage or crushing of organisms. Andrulewicz et al. [10] examined the environmental impact of the installation of a buried submarine power cable on soft bottoms of the Baltic Sea. They concluded that there were no significant changes in benthic diversity, abundance or biomass on the cable route or in its close proximity one year after the installation.

The magnitude and significance of biological changes depend on several factors linked to the sensitivity and resilience capability of the species or communities affected. Habitat or community resilience is characterised by the capacity to return to its initial ecological state after a perturbation (cabling in this case), and the the duration of this response. The weaker the resilience is, the more sensitive the habitat or the community. Thus resilience depends on several factors, including: the nature and stability of the substratum [26-28], habitat depth [24,29] and life cycle of disturbed species (for example, seagrass meadows, which grow very slowly, may take several years to recolonise a disturbed area [30]).

The magnitude of biological changes is also dependent on the composition of the community itself, i.e., the relative occurrence of benthic species (abundance and biomass) and assemblages (richness) along the cable route, compared with their occurrence at the regional scale. Due to the small spatial footprint of cabling, the overall impact on benthic communities is negligible if its spatial distribution is significantly homogeneous.

Benthic community resilience after commissioning of submarine cables remains poorly understood owing to the lack of long-term studies (i.e. occurring several years). Despite the relatively small spatial footprint affected by SPC operations, future studies should focus on the resilience of habitats and communities of particular ecological or economic interest (e.g. sea grass, maerl beds and nursery areas). 


\subsection{Sediment resuspension}

Depending on the nature of the seafloor, sediment reworking by installation, maintenance or decommissioning can lead to turbid plumes that can reach several tens of hectares, with suspended particulate matter concentrations that can reach several dozen $\mathrm{mg} \mathrm{l}^{-1}$ [31]. Apart from sediment type, the extent and properties of plumes will depend on factors such as installation technique, hydrodynamic conditions and the scale of cable-laying. For instance, in the Nysted offshore wind farm (Denmark) where the substrate is dominated by medium sand sediment, cable installation in water depths between 6 and $9.5 \mathrm{~m}$, generated mean particle concentrations of $14 \mathrm{mg} \mathrm{l}^{-1}$ (up to $75 \mathrm{mg} \mathrm{l}^{-1}$ ) at $200 \mathrm{~m}$ from the operation site during trenching with a backhoe dredger, and $2 \mathrm{mg} \mathrm{l}^{-1}$ (up to $18 \mathrm{mg} \mathrm{l}^{-1}$ ) during jetting (Seacon, 2005 in [20]) . Turbidity can persist for several days depending on the duration of the whole cable-laying process. At the Nysted offshore wind farm, one month was necessary to excavate $17,000 \mathrm{~m}^{3}$ of sediment for a $10.3-\mathrm{km}$ long, 1.3-m wide and 1.3-m deep cable trench [32]. However, at any given location on a cable route, disturbance will typically persist from a few hours to a few days.

Decrease in water transparency and deposition of the resuspended material may limit light for primary producers and impact feeding ability of fish that detect their prey visually [33]. The efficiency of invertebrate filter-feeding could also be temporarily modified [34,35]. Resuspension/deposition processes through the plume may bury the eggs of bottom laying species. The presence of mineral particles in the water column may also lead to gill damage in young fish larvae [36,37]. For example, early survival of cod recruits (whose eggs are pelagic) may be affected by the sediment plume created by cable trenching [38].

Nevertheless, turbidity increases resulting from cable installation and decommissioning constitute localised and short-term effects. Although no study has focused on the impact of particle resuspension induced by cable installation and decommissioning on marine communities, it should generally have negligible impacts on marine ecosystems.

\subsection{Chemical pollution}

The main chemical risk is the potential release of sediment-buried pollutants (e.g., heavy metals and hydrocarbons) during sediment re-suspension caused by cable burial, decommissioning or repair works. The highest contaminant concentrations are generally located in coastal areas due to human activities. A preliminary analysis to assess the level of sediment toxicity should be performed in potentially polluted areas to select a cable route which avoids the remobilisation and dispersion of pollutants [39]. 
Pollution can also occur during the operation phase, especially for monopolar DC cables using sea electrodes for the return current path (which represent around 30\% of HVDC in service use [40]). Indeed, the cathode and the anode of sea electrodes release toxic electrolysis products like chlorine and bromine which can impact the immediate water quality [10,40]. To a lesser extent, some older cables have hydrocarbon fluid insulation and may leak contaminants into the marine environment when damaged. The amount of fluid released will vary according to the time needed to detect and repair the leakage, its location and the extent of the damage, but in worst cases several tens of litres can be released per hour (Schreiber et al. 2004, in [41]). It should be noted that installation of oil-insulated cables ceased in the 1990s [42]. Furthermore, ships and hydraulic equipment pose a higher potential risk of accidental oil leakage during operations [23,43]. Cables also include copper, lead and other heavy metals that are potential sources of contamination. For example, a cable consisting of a 3.5-mm lead sheath contains $12 \mathrm{~kg} \mathrm{lead} \mathrm{m}^{-1}$ (Schreiber et al., 2004 in [41]). Heavy metals can potentially dissolve and spread into the sediment from damaged and abandoned cables, but the quantities released are considered insufficient to have significant impacts. Furthermore, such pollution is rare as cables are usually removed when no longer in operation. Although no studies focus specifically on SPC-related contaminants, this source of disturbance is considered to be rare, spatially localised and unlikely to have significant impacts on benthic communities.

\subsection{Underwater noise}

Anthropogenic noise can be produced during route clearance, trenching and backfilling, cable and cable protection introduction by the vessels and tools used during these operations. Intensity and propagation of underwater noise will vary according to bathymetry, seafloor characteristics (e.g., sediment type and topography), vessels and machines used, and water column properties. In-situ data on such noise is scarce, and modelling approaches have been used to estimate the sound pressure levels (SPL) expected during installation. Nedwell and Howell [44] examined the noise produced by plough trenching in a sandy gravel area for the installation of an electric cable within a Welsh offshore wind farm. Results showed a maximal noise emission of $178 \mathrm{~dB}$ re $1 \mu \mathrm{Pa}$ (on a frequency range from 0.7 to $50 \mathrm{kHz}$ ) at $1 \mathrm{~m}$ from the trenching area. A similar study by Bald et al. [45] focused on noises from trenching and cable installation of a wind-farm platform in a sandy area in the Bay of Biscay. During the installation phase, average sound level was $188.5 \mathrm{~dB}$ re $1 \mu \mathrm{Pa}$ (at $11 \mathrm{kHz}$ ) at $1 \mathrm{~m}$ from the source. Modelling using these in situ data estimated that the underwater noise would remain above $120 \mathrm{~dB}$ re $1 \mu \mathrm{Pa}$ in an area of $400 \mathrm{~km}^{2}$ around the source. 
Another, albeit lesser, noise emission caused by submarine cables comes from vibrations during operation of several kinds of HVAC (High Voltage Alternating Current) cables because of the Coulomb force occurring between conductors [46]. For example, a $138 \mathrm{kV}$ transmission cable situated in Canada emits a SPL, for the $120 \mathrm{~Hz}$ tonal vibration, of approximately $100 \mathrm{~dB}$ re $1 \mu \mathrm{Pa}$ at $1 \mathrm{~m}$ [47]. Compared to cable installation, such SPL is low, but continuous because it occurs during the whole operation phase.

There is no clear evidence that underwater noises emitted during cable installation affect marine mammals or any other marine animal, although it is accepted that many marine animals (notably mammals and fishes) detect and emit sounds for different purposes such as communication, orientation or feeding. Marine mammals have high frequency functional hearing ranges from $10 \mathrm{~Hz}$ to $200 \mathrm{kHz}$ [48], while fish typically hear at much lower frequencies, often from $15 \mathrm{~Hz}$ to $1 \mathrm{kHz}$ [49]. Other taxa, organisms including sea turtles [50,51] and many invertebrates such as decapods [52], cephalopods [53,54] or cnidarians [55] have also been shown to be sound-sensitive. Many studies highlight the reaction of cetaceans to anthropogenic sounds of different intensities [56,57]. Sounds generated by ship activity can impact the behaviour of different fish species [58,59]. Anthropogenic underwater noise can affect marine life in different ways, by inducing species to avoid areas, disrupting feeding, breeding or migratory behaviour, masking communication and even causing animal death [60]. So far, characterisation of acoustic thresholds causing temporary or permanent physical damage are much better described for marine mammals $[61,62]$, than for fish [63], and remain unknown for marine invertebrates and sea turtles [64].

Compared with other anthropogenic sources of noise, such as sonar, piling or explosions, underwater noise linked to undersea cables remain low. Cable installation is a spatially localised temporary event, so the impact of noise on marine communities is expected to be minor and brief. HVAC cable vibration, although significantly lower than potential SPL during the installation phase, requires special attention though because its long-term impacts remain unknown.

\subsection{Reef effect}

Like other immersed objects (e.g. shipwrecks, oil/gas platforms, and MRE devices) unburied submarine cables and associated protection/stabilisation can create artificial reefs, inducing the so-called 'reef' effect [65]. Artificial reefs have been commonly used for centuries to enhance fisheries, and more recently for habitat rehabilitation or coastal protection [66]. These structures are colonised by hard-substrate 
benthic species including epifauna and mobile macrofauna, and may also attract mobile megafauna, such as decapods or fishes.

The extent of the reef effect depends on the size and nature of the cable protection structure, but also the characteristics of the surrounding area and native populations [65]. Such artificial structures are expected to have limited reef effects when located within a naturally hard substratum environment. For example, Sherwood et al. [14], looking at the effects of laying and operating the BassLink HVDC cable, found that, 3.5-years after the cable installation, the benthic sessile community present on the half-shell cover was similar to the surrounding basalt reef area (Figure 5.A). Similar investigations showed no significant differences between communities on powered cables and hard bottom control areas $[9,12,67]$. By contrast, on soft sediments, unburied cables generate a stronger reef effect and host a new community, as illustrated by the unburied sections of the ATOC/Pioneer cable (Half Moon Bay, California) colonised by actinarians [13]. In this case, sea anemones became more abundant on the cable than on the surrounding soft bottom 8 years after cable installation (Figure 5.B) and fish species were more abundant close to the cable, probably in response to increased habitat complexity compared with the surrounding environment.

'Reef effect' is usually considered to be a positive anthropogenic impact, as artificial reefs generally have higher densities and biomass of fish and decapod crustaceans than surrounding soft bottoms. Also, when associated with a fisheries exclusion area (as described in section 4.6), artificial reefs may function as refuges for these populations, with potential spill-over benefits for adjacent stocks and fisheries [68]. This is particularly true for commercial species, like the European lobster (Homarus gammarus) or edible crab (Cancer pagurus) observed on offshore wind-farm foundations [69,70]. In some cases, the cable reef effect is considered a compensatory measure for habitat destroyed during cable installation [65]. Concerning dynamic cables used to connect offshore floating MRE projects, in addition to the processes of colonisation and concentration, biofouling can significantly increase cable weight and wear at least on the first tens of metres, creating technical problems [71].

On the other hand, reef effect may potentially result in long-term negative effects if the structures facilitate the introduction of non-indigenous sessile species. Indeed, the number of non-native species present on new hard artificial substrate can be 2.5 times higher than on natural substratum [72]. Thus, the presence of a new hard substratum, such as a cable or its protection structures, on soft sediment can potentially open a corridor to a new area for some hard-bottom sessile species. Such processes can 
potentially lead to the spread of new introduced species by a stepping stone process across biogeographical boundaries [73]. Although cable routes are narrow and often buried in areas of soft sediment, and no spread of invasive species caused by SPC has been documented, this question needs to be considered in light of the exponential growth of offshore wind farms.

\subsection{Reserve effect}

The potential reserve effect of SPC is linked to the limitation/interdiction by local authorities of environmentally damaging human activities (trawl fishing, anchoring, dredging, etc.) around the cable route during the operation phase and is considered as a positive effect for ecosystems. In some cases, the use of passive fishing equipment (nets, lines, and traps) is permitted, reducing the protection of targeted species. The size of the protected zone and the level of restriction depend on the cable installation method (buried or unburied), the number of cables present in the area, and the size of the electrical connections. For example, the Cook Strait cables have an extensive protected area to prevent damage to three submarine HVDC cables and one fibre-optic cable which link the North and South Islands of New Zealand over 40 $\mathrm{km}$. An area seven kilometres wide around these cables, where anchoring and fishing of any type are prohibited, was created by New Zealand authorities, corresponding to a marine protected area of approximately $236 \mathrm{~km}^{2}$ (Figure 6; [74]).

With fishing access restricted, economically exploited sedentary species (such as scallops or clams) will be protected throughout their lives, but protection of mobile species (such as fish) will only be effective during the time they live in/pass through the cable area. A study focusing on fish found no significant differences in species richness inside and outside a protection zone [75]. The reserve effect has been clearly demonstrated for some commercial offshore wind farms, including their associated electric cable grids. Within the Dutch offshore wind farm Egmond aan Zee, where all nautical activities are prohibited, the habitat heterogeneity [76], benthic biodiversity and possibly the use of the area by the benthos, fishes, marine mammals and some bird species have increased (although counterbalanced by a decreasing use of several other bird species). These changes occurred during the first two years of wind-farm operation, in response to the establishment of the marine protected area but also other factors, such as the reef effect of the wind turbine foundations, rockfill and cables. Nenadovic [77] studied a protected area associated with a fibre-optic cable route on the coast of the Gulf of Maine (USA) and showed a significant difference in epifaunal community structure between protected and unprotected areas. In particular, engineer species 
were more frequent near the cable route. The maintenance of such species with a complex biological structure highlights the structuring effect of marine protected areas.

\subsection{Electromagnetic fields}

The potential ecological impacts of electromagnetic fields (EMF) are of particular concern. EMF are generated by current flow passing through power cables during operation and can be divided into electric fields (called E-fields, measured in volts per metre, $\mathrm{V} \mathrm{m}^{-1}$ ) and magnetic fields (called B-fields, measured in $\mu \mathrm{T}$ ). Electric fields increase in strength as voltage increases and may reach $1000 \mu \mathrm{V} \mathrm{m}^{-1}$ for an electric cable [78], but are generally effectively confined inside cables by armouring. EMF characteristics depend on the type of cable (distance between conductors, load balance between the three phases in the cable, etc.), power and type of current (direct vs. alternating current - AC generates an alternating magnetic field which creates a weak induced electric field of a few $\mu \mathrm{V} \mathrm{m}^{-1}$, called an iE-field, near the cable), and whether it is buried or not $[8,79]$. When the cable is buried, the sediment layer does not entirely eliminate the EMF, but reduces exposure to the strongest EMF existing in direct contact with the cable [80]. The strength of both magnetic and induced electric fields increases with current flow and rapidly declines with distance from the cable [81].

Electric currents with intensities of $1600 \mathrm{~A}$ are common in submarine cables. In response, magnetic fields of approximately $3200 \mu \mathrm{T}$ are generated, decreasing to $320 \mu \mathrm{T}$ at $1 \mathrm{~m}$ distance, $110 \mu \mathrm{T}$ at $4 \mathrm{~m}$ and values similar to the terrestrial magnetic field $(50 \mu \mathrm{T})$ beyond $6 \mathrm{~m}$ [82]. By contrast, according to AWATEA [83], a standard submarine cable carrying $132 \mathrm{kV} \mathrm{AC} \mathrm{(350} \mathrm{A)} \mathrm{generates} \mathrm{a} \mathrm{magnetic} \mathrm{field} \mathrm{of} 1.6$ $\mu \mathrm{T}$ on the "skin" of the cable (i.e., within millimetres), while cables carrying 10-15 kV DC do not generate a significant magnetic field beyond a few centimetres from the cable surface. The magnetic field varies greatly as a function of the cable type, and modelling of the magnetic field induced by either DC (Figure 7.A) or AC cables (Figure 7.B) reveals this heterogeneity (1 to $160 \mu \mathrm{T}$ at the cable surface; [81]). Particular attention must be paid to monopolar DC cables using sea electrodes for the return current path, the design of which leads to higher magnetic and electric fields [40,81]. Although modelling presents serious limitations in the understanding of ecosystem-scale responses to such disturbances, the rare in-situ EMF studies available for review yielded values of measured EMF comparable to those calculated by modelling $[10,14]$. 
Many marine species around the world are known to be sensitive to electromagnetic fields, including elasmobranchs (rays and sharks), fishes, mammals, turtles, molluscs and crustaceans. Indeed, the majority of these taxa detect and utilize Earth's geomagnetic field for orientation and migration [84-88]. Some are electrosensitive, like elasmobranchs, which are able to detect E-fields and iE-fields through specific organs called ampullae of Lorenzini $[89,90]$. This electrosense can be used to detect electric fields emitted by prey, conspecifics or potential predators, as well as for orientation [90]. A few incidents of bites observed on unburied SPC may also be linked to the electric field emitted by cables.

Thus, SPC can possibly interact in a negative way with sensitive marine species, especially benthic and demersal organisms through:

- $\quad$ effects on predator/prey interactions,

- avoidance/attraction and other behavioural effects,

- effects on species navigation/orientation capabilities,

- $\quad$ and physiological and developmental effects.

Elasmobranchs can detect very low electric fields( starting from $0.005 \mu \mathrm{V} \mathrm{cm}^{-1}$ [81]), and magnetic (20-75 $\mu \mathrm{T}[82,86])$. Power cables inducing a strong electric field can repel many elasmobranch species, preventing some movement between important areas (such as feeding, mating and nursery areas). As part of the COWRIE (Collaborative Offshore Wind energy Research Into the Environment) project, Gill et al. [91] reported that elasmobranchs are attracted by electric fields generated by DC between 0.005 and $1 \mu \mathrm{V} \mathrm{cm}{ }^{-1}$, and repelled by electric fields of approximately $10 \mu \mathrm{V} \mathrm{cm} \mathrm{cm}^{-1}$ and higher. Mesocosm studies (COWRIE project) on impacts of EMF emitted by submarine cables on several elasmobranch species showed that the response was not predictable and seemed to be species specific, maybe even specific to individuals [92]. Teleosts, especially diadromous fish, also use natural EMF to migrate. Westerberg and Lagenfelt [16] showed that the swimming velocity of European eel (Anguilla anguilla) slightly decreased when crossing the electromagnetic field of a non-buried $130 \mathrm{kV}$ cable, but did not report evidence of population-scale impact. Furthermore, no substantial impacts have been shown on physiology or survival of these taxa $[93,94]$.

Concerning invertebrates, data are scarce except for a few studies relating to minor or nonsignificant impacts of anthropogenic electromagnetic fields on benthic invertebrates $[15,17,93,95,96]$. However, a recent experimental study performed by Hutchison et al. [97], highlights a subtle change in the 
behavioural activity of the American lobster (Homarus americanus) when exposed to EMF from a HVDC cable.

Another noteworthy issue is that substantial data gaps exist between the interaction of pelagic species (like pelagic shark, marine mammals or fishes) and dynamic cables. These gaps remain partly owing to difficulties in evaluating impacts at population scale around these deployments.

\subsection{Heat emission}

When electric energy is transported, a certain amount is lost as heat by the Joule effect, leading to an increase in temperature at the cable surface and a subsequent warming of the immediate surrounding environment [98]. Constant water flow around a laid-down or a dynamic cable tends to dissipate thermal energy and confines it to the cable surface [18]. However, for buried cables, thermal radiation can significantly warm the surrounding sediment in direct contact with the cable, even at several tens of centimetres away from it, and especially in the case of cohesive sediments [99]. Heat emission is higher in $\mathrm{AC}$ than $\mathrm{DC}$ cables at equal transmission rates. Heat emission can be modulated by physical characteristics and electrical tension of the cable, burial depth, bottom type (thermal conductivity, thermal resistance, etc.) and physical characteristics of the environment $[19,98,99]$.

Despite the evidence for thermal radiation from subsea cables, very few studies exist on the subject and most consist of numerical modelling $[18,100]$. One of the rare field measurement studies concerned the offshore wind array of Nysted (maximal production capacity of about $166 \mathrm{MW}$ ), in the proximity of two AC cables of 33 and $132 \mathrm{kV}$ buried in a medium sand area, approximately $1 \mathrm{~m}$ deep. Results showed a maximal temperature increase of about $2.5^{\circ} \mathrm{C}$ at $50 \mathrm{~cm}$ directly below the cable [41]. Transposition of these results to other locations is difficult, considering the large number of factors impacting thermal radiation, and other field studies are necessary to gain a better understanding of thermal radiation effects.

Temperature increases near the cable can modify chemical and physical properties of the substratum, such as oxygen concentration profile (redox interface depth) and, indirectly, the development of microorganism communities and/or bacterial activity. Physiological changes in benthic organisms living at the water-sediment interface and in the top sediment layers can also potentially occur $[19,101]$. Temperature radiation can potentially cause small spatial changes in benthic community structure by way of migratory behaviour modification with cryophilic species being excluded from the cable route in favour of other, more tolerant species. 
To our knowledge, the impacts of local temperature increase caused by electric cables on benthic communities (macrofauna diversity or microbial structure and functioning) have rarely been examined, and in-situ investigations are lacking. Furthermore, studies using controlled temperature increases are often unrealistic regarding the extent of suspected warming. This considerable knowledge gap prevents drawing conclusions about ecological impacts of long-lasting thermal radiation on ecosystems, but considering the narrowness of the corridor and the expected weakness of thermal radiation, impacts are not considered to be significant. Nevertheless, new field measurements and experiments are required to fully understand this phenomenon under operational conditions and to assess its impacts on potentially exposed organisms.

\subsection{Entanglement risks}

Before the 1960s, entanglement of mobile megafauna with cables occurred during the operation phase leading, in the worst cases, to lacerations, infections, starvations and drowning of the trapped marine mammals [102]. Technical improvements made since the 1960s for installation of laid-down cables have reduced this risk [3]. Currently, entanglement risks only concern dynamic SPC. Although this risk is considered to be non-significant, concerning a single dynamic SPC (such as pilot scale projects still under development), it may require more attention in the future owing to the growth in commercial farms of floating devices and associated webs of dynamic SPC and mooring lines hanging in the water column. According to Kropp [103], arrays of dozens of dynamic cables and mooring lines per $\mathrm{km}^{2}$ can potentially affect large marine animals, i.e. whales.

According to existing reports, entanglements caused by dynamic SPC will remain a low risk [103,104]. The large diameters of SPC ( $>5 \mathrm{~cm})$ make them relatively inflexible [105], and mooring lines and dynamic SPC should be tight enough to reduce entanglement [103]. However, indirect entanglement resulting from discarded fishing gear wrapped around dynamic SPC [102] may significantly impact a larger set of species, including marine mammals, sharks or fishes. Quantifying such risks will only be possible when floating MRE installations are operational. Consequently, entanglement risk remains highly speculative at this stage, relying on modelling data..

\section{Recommendations}

\subsection{Mitigation and compensation measures}

Potential environmental impacts of cables should be anticipated prior to the installation phase by applying avoidance and reduction measures. In order to mitigate potential environmental disturbances 
caused by cabling activity, measures exist and should be applied, including the choice of an appropriate cable route and installation technique, answering the following:

- Planning the cable route to avoid impacts on habitats and benthic species that are most sensitive to disturbance or are of special ecological interest (with special attention to slow-growing long-lived species). Particularly important and sensitive habitats in the North Atlantic include biogenic reefs comprising Modiolus modiolus (Horse mussel beds), Sabellaria spinulosa (honeycomb worm), maerl beds and Zostera seagrass meadows.

- Selecting landing zones and cable routes in order to prevent the re-mobilisation of contaminants present in sediments and contamination of the trophic food web.

- Using cable technology suitable for reducing the emission of magnetic fields, such as three-phase AC cables and bipolar HVDC transmission systems [39], and minimising the emission of directly generated electric fields through adequate shielding [44].

- Avoiding the use of monopolar DC cables using sea electrodes, which produce toxic compounds, generate higher EMF and accelerate corrosion of manmade structures, in favour of cable systems with other return path options causing less disturbance [40].

- Deploying dynamic SPC with the lowest risks of entanglement for marine megafauna where relevant. Appropriate configurations, as for mooring lines [104], and appropriate cable type, with diameters and colours allowing visual tracking of affected species [103].

- Managing installations with respect to life cycles of mobile species (winter dormancy, migration, mating and/or spawning, etc.), and to avoid disturbance of sensitive species (e.g., fish, crustaceans, marine mammals, marine turtles or resting/feeding birds).

- Prioritizing burial depth appropriate to the substratum type. To reduce exposure of sensitive species to electromagnetic fields and heat emission, the physical distance between animals and the cable can be increased. According to models proposed by Normandeau et al. ([81], Figure 7), the EMF level at the water-sediment interface with a $2 \mathrm{~m}$ burial depth would be approximately $25 \%$ of its initial valueversus $60 \%$ for a $1 \mathrm{~m}$ burial depth.

- Prioritizing the laid-down option rather than burying in the presence of unavoidable fragile benthic soft bottom habitats (e.g., seagrass beds; [11]). 
- Installing devices with a strategy to reduce electrical connections and limiting the number of export cables (i.e., when several MRE projects are present in close proximity).

To complement reduction and avoidance strategies, compensation measures should be considered if residual impacts persist. In this event, and only after having addressed mitigation options, compensation measures may be applied directly to the implantation site, or in close proximity. Discussions between stakeholders are recommended to establish parameters for scale and responsibilities for compensation measures.

A possible form of compensation measures can consist of improving future engineering strategies through experimental studies of ecosystem functioning and resilience following disturbance. For example, on the Paimpol-Bréhat French tidal turbine test site, the cable route connecting turbines to the land crosses important seagrass meadows containing Zostera noltei and Z. marina. In response, the prime contractor (EDF, Electricité De France) developed an experimental protocol aiming to transplant some seagrass plants located on the route area to another barren place before cable burial. Such measures aimed to test transplantation techniques and acquire knowledge about the mechanism of recolonisation by seagrass after installation of a cable [106]. Similar transplantation experiments are currently being tested in the context of SPC installation (e.g., ongoing project by Red Eléctrica de España in Majorca and Ibiza).

Environmental monitoring strategies performed in parallel with cable installation should: (i) verify the impact predictions made in the environmental impact study and detect unforeseen alterations, (ii) ensure the fulfilment of mitigating measures proposed, and (iii) provide data to improve future environmental impact assessments and installation plans [107].

\subsection{Future research priorities}

A hierarchical model of potential impacts based on the expected levels of ecological effects and the associated levels of scientific knowledge (or uncertainty) is presented in table 2. This synthetic output corresponds to a concerted expert judgement of the authors, and takes into account the main conclusions of the literature cited in this paper. The main priorities concern benthic habitat disturbance, reef and reserve effects and potential impacts of EMF. A substantial data gap remains concerning the impacts of EMF because data on sensitivity thresholds or tolerance are only available for a small number of taxa. Major uncertainties therefore remain for several large groups (cetaceans, pinnipeds, fishes, crustaceans, and many pelagic species) [81]. Better knowledge of the different sensitivity thresholds is needed to fill these data 
gaps, especially for several key species at different stages of their development. Additionally, environmental issues may arise following industrial-scale deployment of MRE devices using multiple submarine electric cables installed in close proximity and creating a network impacting a large area. The cumulative effects of more than one activity or perturbation factor, which may act in synergy, must be considered [108]. For example, recovery of benthic communities after cable installation may be slower and less efficient if the benthic ecosystem is already threatened by other anthropogenic disturbances such as chemical pollution, eutrophication, or invasive species (especially in enclosed and shallow areas). The assessment of impacts due to interactions between different kinds of disturbances remains highly speculative, partly since environmental impacts of single cables are still poorly understood.

\section{Conclusions}

Although SPC have been used since the mid-19th century, environmental concerns associated with their installation and operation are much more recent. This is due to an increased awareness of anthropogenic impacts, the rapid expansion of SPC deployments, and the growing demand for electric interconnections between countries that have adopted a common energy strategy.

The main potential environmental impacts associated with SPC during their operational phase are those related to the production of electromagnetic fields, the creation of artificial reefs and "reserve effects" caused by the interdiction of certain human activities. Cable installation, maintenance and decommissioning also impact the environment, causing direct benthic habitat modification, which can be especially problematic in the case of sensitive bioconstructed habitats. These phases of SPC may also induce significant particle and pollutant resuspension events in very confined and modified shallow coastal areas. Mitigation measures are possible before, during or after projects to limit the ecological impacts of SPC and associated maritime operations.

While potential environmental impacts generated by SPC are recognised, better knowledge of amplitude and duration is essential. Generally these disturbances occur over short times scales, creating relatively minor impacts on ecosystem structure and functioning. Nevertheless, the nature and amplitude of certain impacts remain poorly studied, particularly the EMF impacts on elasmobranchs, diadromous fishes and invertebrates, and assessment of cumulative impacts. Despite these knowledge gaps, the present review provides a quantification and ordering of the different impacts of SPC on marine environments and offers updated practical recommendations for developer mitigation strategies. 


\section{Acknowledgements}

3 This work is the result of a collaborative effort between authors of the paper sponsored under EERA

4 (European Energy Research Alliance), UKCMER (UK Centre for Marine Energy Research), Région 5 Bretagne and the National Research Agency under the Investments for the Future program bearing the 6 reference ANR-10-IED-0006-17. The authors would like to thank Normandeau Associates Inc., Louis 7 Dreyfus Travocean, the Monterey Bay Aquarium Research Institute, John Sherwood and collaborators as $8 \quad$ well as Olivier Dugornay for their kind assistance in supplying the different photography and figures. We 9 also thank three anonymous reviewers for constructive criticism and valuable suggestions. Finally, the 10 authors would also like to thank Nolwenn Quillien, Julie Lossent, Guillaume Damblans and Kelly Cayocca 11 for their help. 
References

[1] Ardelean M, Minnebo P. HVDC Submarine Power Cables in the World. State-of-the-Art Knowledge; EUR 27527 EN. 2015. doi:10.2790/95735.

[2] Boehlert GW., Gill AB. Environmental and Ecological Effects Of Ocean Renewable Energy Development. Oceanography 2010;23:68-81. doi:10.5670/oceanog.2010.46.

[3] Wood MP, Carter L. Whale entanglements with submarine telecommunication cables. IEEE J Ocean Eng 2008;33:445-50. doi:10.1109/JOE.2008.2001638.

[4] International Cable Protection Committee. Submarine Cables and BBNJ. 2016.

[5] Carter L, Burnett D, Drew S, Marle G, Hagadorn L, Bartlett-McNeil D, et al. Submarine Cables and the Oceans - Connecting the World. UNEP-WCMC Biodivers Ser 2009;31.

[6] Edenhofer O, Pichs-Madruga R, Sokona Y, Kristin S, Matschoss P, Kadner S. Summary for Policymakers. In: IPCC Special Report on Renewable Energy Sources and Climate Change Mitigation, Cambridge: Cambridge University Press; 2011.

[7] Lindeboom H, Degraer S, Dannheim J, Gill AB, Wilhelmsson D. Offshore wind park monitoring programmes, lessons learned and recommendations for the future. Hydrobiologia 2015;756:16980. doi:10.1007/s10750-015-2267-4.

[8] Copping A, Sather N, Hanna L, Whiting J, Zydlewsk G, Staines G, et al. Annex IV 2016 State of the Science Report: Environmental Effects of Marine Renewable Energy Development Around the World 2016. doi:10.1097/JNN.0b013e3182829024.

[9] Dunham A, Pegg JR, Carolsfeld W, Davies S, Murfitt I, Boutillier J. Effects of submarine power transmission cables on a glass sponge reef and associated megafaunal community. Mar Environ Res 2015;107:50-60. doi:10.1016/j.marenvres.2015.04.003.

[10] Andrulewicz E, Napierska D, Otremba Z. The environmental effects of the installation and functioning of the submarine SwePol Link HVDC transmission line: A case study of the Polish Marine Area of the Baltic Sea. J Sea Res 2003;49:337-45. doi:10.1016/S1385-1101(03)00020-0.

[11] Bacci T, Rende SF, Nonnis O, Maggi C, Izzi A, Gabellini M, et al. Effects of laying power cables on a Posidonia oceanica (L.) Delile prairie: The study case of Fiume Santo (NW Sardinia, Italy). J Coast Res 2013;65:868-73. doi:10.2112/SI65-147.

[12] Love MS, Nishimoto MM, Clark S, Mccrea M, Bull AS. The Organisms Living Around Energized 
Submarine Power Cables, Pipe, and Natural Sea Floor in the Inshore Waters of Southern California. Bull South Calif Acad Sci 2017;116:61-87.

[13] Kogan I, Paull CK, Kuhnz LA, Burton EJ, Von Thun S, Gary Greene H, et al. ATOC/Pioneer Seamount cable after 8 years on the seafloor: Observations, environmental impact. Cont Shelf Res 2006;26:771-87. doi:10.1016/j.ejor.2004.05.021.

[14] Sherwood J, Chidgey S, Crockett P, Gwyther D, Ho P, Stewart S, et al. Installation and operational effects of a HVDC submarine cable in a continental shelf setting: Bass Strait, Australia. J Ocean Eng Sci 2016;1:337-53. doi:10.1016/j.joes.2016.10.001.

[15] Love MS, Nishimoto MM, Clark S, Bull AS. Identical Response of Caged Rock Crabs (Genera Metacarcinus and Cancer) to Energized and Unenergized Undersea Power Cables in Southern California, USA. Bull South Calif Acad Sci 2015;114:33-41. doi:10.3160/0038-3872-114.1.33.

[16] Westerberg H, Lagenfelt I. Sub-sea power cables and the migration behaviour of the European eel. Fish Manag Ecol 2008;15:369-75. doi:10.1111/j.1365-2400.2008.00630.x.

[17] Love MS, Nishimoto MM, Clark S, McCrea M, Bull AS. Assessing potential impacts of energized submarine power cables on crab harvests. Cont Shelf Res 2017;151:23-9. doi:10.1016/j.csr.2017.10.002.

[18] Worzyk T. Submarine Power Cables: Design, Installation, Repair, Environmental Aspects. Power Syst 2009;39. doi:10.1007/978-3-642-01270-9.

[19] OSPAR Commission. Background document on potential problems associated with power cables other than those for oil and gas activities. 2008.

[20] Vize S, Adnitt C, Stanisland R. Review of cabling techniques and environmental effects applicable to the offshore wind farm industry (BERR Technical Report). 2008.

[21] Rees J, Larcombe P, Vivian C, Judd A. Scroby Sands Offshore Wind Farm - Coastal Processes Monitoring . Final Report. 2006.

[22] Wilhelmsson D, Malm T, Thompons R, Tchou J, Sarantakos G, McCormick N, et al. Greening Blue Energy: Identifying and managing the biodiversity risks and opportunies of offshore renewable energy. IUCN; 2010.

[23] Bald J, Campo A, Franco J, Galparsoro I, Gonzalez M, Liria P, et al. Protocol to develop an environmental impact study of wave energy converters. Rev Investig Mar 2010;17:62-138. 
[24] Foden J, Rogers SI, Jones AP. Human pressures on UK seabed habitats: A cumulative impact assessment. Mar Ecol Prog Ser 2011;428:33-47. doi:10.3354/meps09064.

[25] Borja Á, Galparsoro I, Irigoien X, Iriondo A, Menchaca I, Muxika I, et al. Implementation of the European Marine Strategy Framework Directive: A methodological approach for the assessment of environmental status, from the Basque Country (Bay of Biscay). Mar Pollut Bull 2011;62:889-904. doi:10.1016/j.marpolbul.2011.03.031.

[26] Foden J, Rogers SI, Jones AP. Recovery of UK seabed habitats from benthic fishing and aggregate extraction-Towards a cumulative impact assessment. Mar Ecol Prog Ser 2010;411:259-70. doi:10.3354/meps08662.

[27] Kaiser MJ, Clarke KR, Hinz H, Austen MC V, Somerfield PJ, Karakassis I. Global analysis of response and recovery of benthic biota to fishing. Mar Ecol Prog Ser 2006;311:1-14. doi:10.3354/meps311001.

[28] Newell RC, Seiderer LJ, Hitchcock DR. the Impact of Dredging Works in Coastal Waters: a Review of the Sensitivity To Disturbance and Subsequent Recovery of Biological Resources on the Sea Bed. Oceanogr Mar Biol an An Nual Rev 1998;36:127-78.

[29] Clark MR, Althaus F, Schlacher TA, Williams A, Bowden DA, Rowden AA. The impacts of deepsea fisheries on benthic communities : a review. ICES J Mar Sci 2016;73:51-69.

[30] Erftemeijer PLA, Robin Lewis III RR. Environmental impacts of dredging on seagrasses : A review. Mar Pollut Bull 2006;52:1553-72. doi:10.1016/j.marpolbul.2006.09.006.

[31] Fissel DB, Jiang J. Three-Dimensional Numerical Modeling of Sediment Transport For Coastal Engineering Projects in British Columbia, Canada. Ocean. - MTS/IEEE Kona, Progr. B., 2011.

[32] Dong Energy. The Danish offshore wind farm, demonstration projects: Horns Rev and Nysted offshore wind farms. Environmental impact assessment and monitoring. 2006.

[33] Utne-Palm a. C. Visual feeding of fish in a turbid environment: Physical and behavioural aspects. Mar Freshw Behav Physiol 2002;35:111-28. doi:10.1080/10236240290025644.

[34] Last KS, Hendrick VJ, Beveridge CM, Davies a J. Measuring the effects of suspended particulate matter and smothering on the behaviour, growth and survival of key species found in areas associated with aggregate dredging. Report for the Marine Aggregate Levy Sustainability Fund, Project MEPF 08/P76. 2011. 
[35] Szostek CL, Davies AJ, Hinz H. Effects of elevated levels of suspended particulate matter and burial on juvenile king scallops Pecten maximus. Mar Ecol Prog Ser 2013;474:155-65. doi:10.3354/meps 10088 .

[36] Au DW. T, Pollino CA, Wu RSS, Shin PKS, Lau STF, Tang JYM. Chronic effects of suspended solids on gill structure, osmoregulation, growth, and triiodothyronine in juvenile green grouper Epinephelus coioides. Mar Ecol Prog Ser 2004;266:255-64. doi:10.3354/meps266255.

[37] Wong CK, Pak IAP, Jiang Liu X. Gill damage to juvenile orange-spotted grouper Epinephelus coioides (Hamilton, 1822) following exposure to suspended sediments. Aquac Res 2013;44:168595. doi:10.1111/j.1365-2109.2012.03173.x.

[38] Hammar L, Wikström A, Molander S. Assessing ecological risks of offshore wind power on Kattegat cod. Renew Energy 2014;66:414-24. doi:10.1016/j.renene.2013.12.024.

[39] Merck T, Wasserthal R. Assessment of the environmental impacts of cables. OSPAR Biodivers Ser 2009;437:18 pp.

[40] Sutton SJ, Lewin PL, Swingler SG. Electrical Power and Energy Systems Review of global HVDC subsea cable projects and the application of sea electrodes 2017;87:121-35. doi:10.1016/j.ijepes.2016.11.009.

[41] Meißner K, Schabelon H, Bellebaum J, Sordyl H. Impacts of submarine cables on the marine environment: A literature review. 2006.

[42] Carter L, Burnett D, Davenport T. The relationship between submarine cables and the marine environment. In: Burnett D, Beckman R, Davenport T, editors. Submar. Cables Handb. Law Policy, Martinus Nijhoff Publishers; 2013, p. 179-212. doi:10.1016/S0262-4079(09)63022-0.

[43] Polagye B, Van Cleve B, Copping A, Kirkendall K. Environmental Effects of Tidal Energy Development 2011:1-190.

[44] Nedwell J, Howell D. A review of offshore windfarm related underwater noise sources. 2004. doi:10.1093/cid/cir102.

[45] Bald J, Hernández C, Uriarte A, Castillo JA, Ruiz P, Ortega N, et al. Acoustic characterization of submarine cable installation in the Biscay Marine Energy Platform (BIMEP). Bilbao Energy Week 2015,2015

[46] Zabar Z, Birenbaum L, Cheo BR, Joshi PN, Spagnolo A. A detector to identity a de-energized 
feeder among a group of live ones. IEEE Trans Power Deliv 1992. doi:10.1109/61.156984.

[47] JASCO Research Ltd. Vancouver Island Transmission Reinforcement Project : Atmospheric and Underwater Acoustics Assessment Report. Prepared for British Columbia Transmission Corporation. 2006.

[48] Richardson WJ, Greene CR, Malme CI, Thomson DH, Moore SE, Wiirsig B. Marine Mammals and Noise. San Diego: Academic Press; 2013. doi:10.1016/C2009-0-02253-3.

[49] Gotz T, Hastie G, Hatch LT, Raustein O, Southall BL, Tasker M, et al. Overview of the impacts of anthropogenic underwater sound in the marine environment Biodiversity Series. OSPAR Biodivers Ser 2009;441:1-134.

[50] O'Hara J, Wilcox JR. Avoidance Responses of Loggerhead Turtles, Caretta caretta , to Low Frequency Sound. Copeia 1990;1990:564-7. doi:10.1105/tpc.105.036806.osmotic.

[51] Bartol SM, Musick JA, Lenhardt ML. Auditory Evoked Potentials of the Loggerhead Sea Turtle ( Caretta caretta ). Copeia 1999;1999:836-40.

[52] Popper AN, Salmon M, Horch KW. Acoustic detection and communication by decapod crustaceans. J Comp Physiol - A Sensory, Neural, Behav Physiol 2001;187:83-9. doi:10.1007/s003590100184.

[53] André M, Solé M, Lenoir M, Durfort M, Quero C, Mas A, et al. Low-frequency sounds induce acoustic trauma in cephalopods. Front Ecol Environ 2011;9:489-93. doi:10.1890/100124.

[54] Packard A, Karlsen HE, Sand O. Low frequency hearing in cephalopods. J Comp Physiol A Sensory, Neural Behav Physiol 1990;166:501-5. doi:10.1007/BF00192020.

[55] Solé M, Lenoir M, Fontuño JM, Durfort M, van der Schaar M, André M. Evidence of Cnidarians sensitivity to sound after exposure to low frequency noise underwater sources. Sci Rep 2016;6:37979. doi:10.1038/srep37979.

[56] Bailey H, Senior B, Simmons D, Rusin J, Picken G, Thompson PM. Assessing underwater noise levels during pile-driving at an offshore windfarm and its potential effects on marine mammals. Mar Pollut Bull 2010;60:888-97. doi:10.1016/j.marpolbul.2010.01.003.

[57] Gordon J, Gillespie D, Potter J, Frantzis A, Simmonds MP, Swift R, et al. A Review of the Effects of Seismic Survey on Marine Mammals. Mar Technol Soc J 2003;37:16-34. doi:10.4031/002533203787536998. 
[58] Popper AN, Hastings MC. The effects of human-generated sound on fish. Integr Zool 2009;4:4352. doi:10.1111/j.1749-4877.2008.00134.x.

[59] Sarà G, Dean JM, D’Amato D, Buscaino G, Oliveri A, Genovese S, et al. Effect of boat noise on the behaviour of bluefin tuna Thunnus thynnus in the Mediterranean Sea. Mar Ecol Prog Ser 2007;331:243-53. doi:10.3354/meps331243.

[60] Rossington K, Benson T, Lepper P, Jones D. Eco-hydro-acoustic modeling and its use as an EIA tool. Mar Pollut Bull 2013;75:235-43. doi:10.1016/j.marpolbul.2013.07.024.

[61] National Marine Fisheries Service. Technical Guidance for Assessing the Effects of Anthropogenic Sound on Marine Mammal Hearing : Underwater Acoustic Thresholds for Onset of Permanent and Temporary Threshold Shifts. 2016.

[62] Southall BL, Bowles AE, Ellison WT, Finneran JJ, Gentry RL, Greene Jr CR, et al. Marine mammal Noise Exposure Criteria: Initial Scientific Recommendations. Aquat Mamm 2007;33:511-21. doi:10.1578/AM.33.4.2007.411.

[63] Slabbekoorn H, Bouton N, van Opzeeland I, Coers A, ten Cate C, Popper AN. A noisy spring: The impact of globally rising underwater sound levels on fish. Trends Ecol Evol 2010;25:419-27. doi:10.1016/j.tree.2010.04.005.

[64] Popper AN, Hawkins AD, Fay RR, Mann DA, Bartol S, Carlson TJ, et al. Sound Exposure Guidelines for Fishes and Sea Turtles. 2014. doi:10.1007/978-3-319-06659-2.

[65] Langhamer O. Artificial Reef Effect in relation to Offshore Renewable Energy Conversion: State of the Art. Sci World J 2012;2012:e386713. doi:10.1100/2012/386713.

[66] Jensen AC, Collins KJ, Lockwood APM. Artificial Reef In European Seas. Springer Netherlands; 2000. doi:10.1007/978-94-011-4215-1.

[67] Kuhnz LA, Buck K, Lovera C, Whaling PJ, Barry JP. Potential impacts of the Monterey Accelerated Research System (MARS) cable on the seabed and benthic faunal assemblages. 2015. doi:10.1017/CBO9781107415324.004.

[68] Wilhelmsson D, Langhamer O. The Influence of Fisheries Exclusion and Addition of Hard Substrata on Fish and Crustaceans. In: Shields MA, Payne ILA, editors. Mar. Renew. energy Technol. Environ. Interact., Springer; 2014, p. 49-60.

[69] Hooper T, Austen M. The co-location of offshore windfarms and decapod fisheries in the UK: 
Constraints and opportunities. Mar Policy 2014;43:295-300. doi:10.1016/j.marpol.2013.06.011.

[70] Krone R, Dederer G, Kanstinger P, Krämer P, Schneider C, Schmalenbach I. Mobile demersal megafauna at common offshore wind turbine foundations in the German Bight (North Sea) two years after deployment - increased production rate of Cancer pagurus. Mar Environ Res 2017;123:53-61. doi:10.1016/j.marenvres.2016.11.011.

[71] Yang S, Ringsberg JW, Johnson E, Hu Z. Biofouling on mooring lines and power cables used in wave energy converter systems - Analysis of fatigue life and energy performance. Appl Ocean Res 2017;65:166-77. doi:10.1016/j.apor.2017.04.002.

[72] Glasby TM, Connell SD, Holloway MG, Hewitt CL. Nonindigenous biota on artificial structures: Could habitat creation facilitate biological invasions? Mar Biol 2007;151:887-95. doi:10.1007/s00227-006-0552-5.

[73] Adams TP, Miller RG, Aleynik D, Burrows MT. Offshore marine renewable energy devices as stepping stones across biogeographical boundaries. J Appl Ecol 2014;51:330-8. doi:10.1111/13652664.12207

[74] TRANSPOWER. An information brochure on the Submarine Cable Protection Zone across Cook Strait and how it affects mariners, fishers, divers and the public. 2011.

[75] Shears NT, Usmar NR. The role of the Hauraki Gulf Cable Protection Zone in protecting exploited fish species : de facto marine reserve? DOC Res Dev Ser 2006;253:27.

[76] Lindeboom HJ, Kouwenhoven HJ, Bergman MJN, Bouma S, Brasseur S, Daan R, et al. Short-term ecological effects of an offshore wind farm in the Dutch coastal zone; a compilation. Environ Res Lett 2011;6:1-13. doi:10.1088/1748-9326/6/3/035101.

[77] Nenadovic M. The Effects Of Bottom-Tending Mobiles Fishing Gear and Fiber-Optic Cable Burial On Soft-Sediment Benthic Community Structure. University of Maine, 2009.

[78] Gill AB, Taylor H. The potential effects of electromagnetic fields generated by cabling between offshore wind turbines upon Elasmobranch Fishes. - CCW Science Report 2001:76.

[79] Ohman MC, Sigray P, Westerberg H. Offshore windmills and the effects of electromagnetic fields on fish. Ambio 2007;36:630-3. doi:10.1579/0044-7447(2007)36.

[80] CMACS. A baseline assessment of electromagnetic fields generated by offshore windfarm cables. COWRIE Report EMF - 01-2002 66. 2003. 
[81] Normandeau Associates Inc., Exponent Inc., Tricas T, Gill A. Effects of EMFs from Undersea Power Cables on Elasmobranchs and Other Marine Species. 2011.

[82] Bochert R, Zettler ML. Effect of electromagnetic fields on marine organisms geomagnetic field detection in marine organisms. Offshore Wind Energy Res Environ Impacts 2006:223-34. doi:10.1007/978-3-540-34677-7_14.

[83] AWATEA. Environmental Impacts of Marine Energy Converters. Prepared for the Energy Efficiency and Conservation Authority. 2008.

[84] Kirschvink JL. Magnetoreception: Homing in on Vertebrates. Nature 1997;390:339-40. doi:10.1038/hdy.2010.69.

[85] Willows AOD. Shoreward orientation involving geomagnetic cues in the nudibranch mollusc Tritonia diomedea. Mar Freshw Behav Physiol 1999;32:181-92. doi:10.1080/10236249909379046.

[86] Walker MM, Dennis TE, Kirschvink JL. The magnetic sense and its use in long-distance navigation by animals. Curr Opin Neurobiol 2002;12:735-44. doi:10.1016/S0959-4388(02)00389-6.

[87] Lohmann KJ, Putman NF, Lohmann CMF. Geomagnetic imprinting: A unifying hypothesis of long-distance natal homing in salmon and sea turtles. Proc Natl Acad Sci U S A 2008;105:19096101. doi:10.1073/pnas.0801859105.

[88] Lohmann KJ, Ernst DA. The geomagnetic sense of crustaceans and its use in orientation and navigation. In: Derby C, Thiel M, editors. Nerv. Syst. Control Behav., Oxford University Press; 2014, p. 321-36.

[89] Peters RC, Eeuwes LBM, Bretschneider F. On the electrodetection threshold of aquatic vertebrates with ampullary or mucous gland electroreceptor organs. Biol Rev 2007;82:361-73. doi:10.1111/j.1469-185X.2007.00015.x.

[90] Gill AB, Gloyne-Philips I, Kimber J, Sigray P. Marine renewable energy, electromagnetic (EM) fields and EM-sensitive animals. In: Shields MA, Payne ILA, editors. Mar. Renew. energy Technol. Environ. Interact., Springer; 2014, p. 61-79. doi:10.1007/978-94-017-8002-5_6.

[91] Gill AB, Gloyne-Phillips I, Neal KJ, Kimber JA. The potential effects of electromagnetic fields generated by sub-sea power cables associated with offshore wind farm developments on electrically and magnetically sensitive marine organisms - a review. 2005. 
[92] Gill AB, Huang Y, Gloyne-philips I, Metcalfe J, Quayle V, Spencer J, et al. COWRIE 2.0 Electromagnetic Fields (EMF) Phase 2: EMF-sensitive fish response to EM emissions from subsea electricity cables of the type used by the offshore renewable energy industry. 2009.

[93] Woodruff D, Schultz I, Marshall K, Ward J, Cullinan V. Effects of Electromagnetic Fields on Fish and Invertebrates Task 2.1.3: Effects on Aquatic Organisms Fiscal Year 2011 Progress Report. 2012.

[94] Gill AB, Bartlett M, Thomsen F. Potential interactions between diadromous fishes of U.K. conservation importance and the electromagnetic fields and subsea noise from marine renewable energy developments. J Fish Biol 2012;81:1791. doi:10.1111/j.1095-8649.2012.03450.x.

[95] Woodruff D, Cullinan VI, Copping AE, Marshall KE. Effects of Electromagnetic Fields on Fish and Invertebrates Task 2.1.3: Effects on Aquatic Organisms Fiscal Year 2012 Progress Report. 2013. doi:10.3109/15368378.2013.776333.

[96] Bochert R, Zettler ML. Long-term exposure of several marine benthic animals to static magnetic fields. Bioelectromagnetics 2004;25:498-502. doi:10.1002/bem.20019.

[97] Hutchison Z, Sigray P, He H, Gill AB, King J, Gibson C. Electromagnetic Field (EMF) Impacts on Elasmobranch (shark, rays, and skates) and American Lobster Movement and Migration from Direct Current Cables. Sterling (VA): U.S. Department of the Interior, Bureau of Ocean Energy Management. OCS Study BOEM 2018-00. 2018. doi:10.13140/RG.2.2.10830.97602.

[98] OSPAR Commission. Guidelines on Best Environmental Practice (BEP) in Cable Laying and Operation. 2012.

[99] Emeana CJ, Hughes TJ, Dix JK, Gernon TM, Henstock TJ, Thompson CEL, et al. The thermal regime around buried submarine high-voltage cables. Geophys J Int 2016;206:1051-64. doi:10.1093/gji/ggw195.

[100] Hughes TJ, Henstock TJ, Pilgrim JA, Dix JK, Gernon TM, Thompson CEL. Effect of Sediment Properties on the Thermal Performance of Submarine HV Cables. IEEE Trans Power Deliv 2015;30:2443-50. doi:10.1109/TPWRD.2015.2398351.

[101] Rhoads DC, Boyer LF. The Effects of Marine Benthos on Physical Properties of Sediments. A Successional Perspective. In: McCall PL, Tevesz MJS, editors. Anim. Relations Biog. Alter. Sediments, Springer US; 1982, p. 3-43. 
[102] Benjamin S, Hamois V, Smith HCM, Johanning L, Greenhill L, Carter C, et al. Understanding the potential for marine megafauna entanglement risk from renewable marine energy developments. Scottish Natural Heritage Commissioned Report No. 791. 2014.

[103] Kropp RK. Biological and Existing Data Analysis to Inform Risk of Collision and Entanglement Hypotheses. 2013.

[104] Harnois V, Smith HCM, Benjamins S, Johanning L. Assessment of entanglement risk to marine megafauna due to offshore renewable energy mooring systems. Int J Mar Energy 2015;11:27-49. doi:10.1016/j.ijome.2015.04.001.

[105] Federal Energy Regulatory Commission. Environmental assessment for hydropower licence : Reedsport OPT Wave Park Project - Project No. 12713-002 Oregon. 2010.

[106] Barillier A, Dubreuil J, Hily C. EDF Paimpol-Bréhat tidal power plant project : first results of experimental restoration of Zostera seagrass. SHF (Société Hydrotechnique Fr. - Mar. Renew. Energy 2013, 2013.

[107] Moura A, Simas T, Batty R, Wilson B, Thompson D, Lonergan M, et al. Scientific guidelines on Environmental Assessment: Equitable Testing and Evaluation of Marine Energy Extraction Devices in terms of Performance, Cost and Environmental Impact. 2010.

[108] Crain CM, Kroeker K, Halpern BS. Interactive and cumulative effects of multiple human stressors in marine systems. Ecol Lett 2008;11:1304-15. doi:10.1111/j.1461-0248.2008.01253.x. 
$2 \quad$ Fig 1. Wheel cutter (left); Plough (centre) and Towed Jetting Vehicle (right) (courtesy:

$3 \quad$ www.ldtravocean.com).

$4 \quad$ Fig 2. Photograph of iron shells and concrete mattresses used to protect an unburied cable at the Paimpol-

$5 \quad$ Bréhat tidal turbine test site, France (courtesy: Olivier Dugornay, 2013).

$6 \quad$ Fig 3. Diagram of the potential impacts caused by different types of SPC immersion (Dynamic, Laid-Down 7 and Buried) during their operation and installation/decommissioning phases.

$8 \quad$ Fig 4. Installation works of the 2000 FLAG Atlantic 1 in the intertidal area, Brittany, France (courtesy:

$9 \quad$ www.ldtravocean.fr).

10 Fig 5. Photographs of laid-down cables: A) the ATOC/Pioneer Seamount cable (California, USA) in an 11 unconsolidated sandy silt area showing three Metridium farcimen settled on the cable (courtesy: [13]); B) 12 the BassLink cable (Tasmania, Australia), protected by a cast-iron half-shell, showing a heavy encrustation 13 of algal and invertebrate species on the underlying basalt reef (courtesy: [14]); and C) the rock mattresses $14 \quad$ used to stabilize the cable connecting the Paimpol-Bréhat tidal turbine test site, France, to the land, showing 15 heavy colonisation by megafauna species like the European lobster (Homarus gammarus) (courtesy: Olivier 16 Dugornay - IFREMER).

$17 \quad$ Fig 6. Protection zone of three SPC and one fibre-optic cable situated across Cook Strait, New Zealand.

18 The total protected area covers approximately $236 \mathrm{~km}^{2}$ (reproduced from [73]).

$19 \quad$ Fig 7. Modelled magnetic fields at the sediment-water interface originating from different types of buried submarine cables in operation; A: Calculated data based on 9 DC cables. B: Calculated data based on 10 ${ }_{21}$ AC cables (courtesy: [80]). 


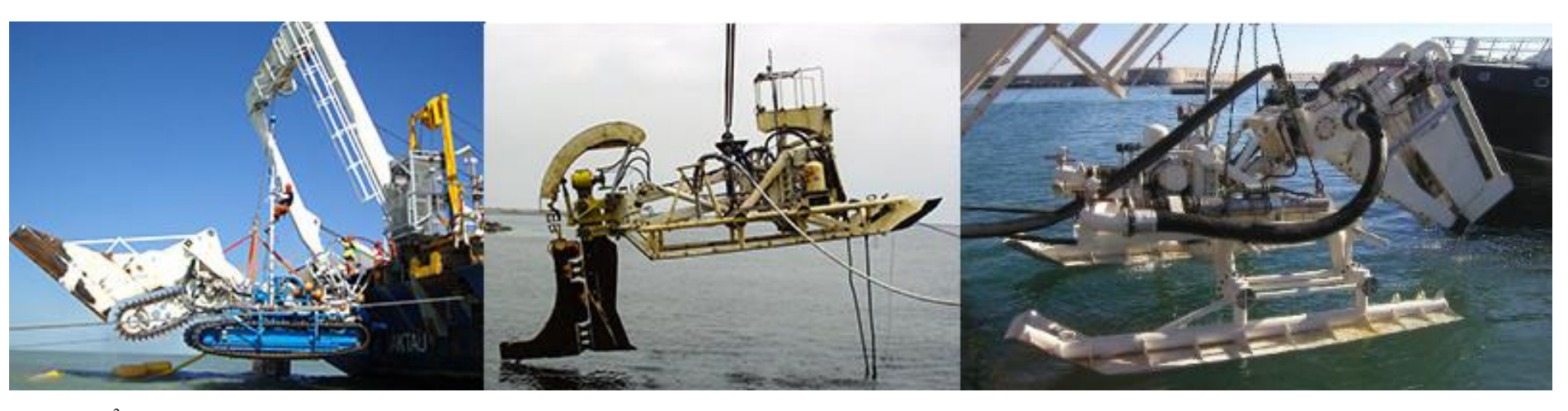

Fig. 1 


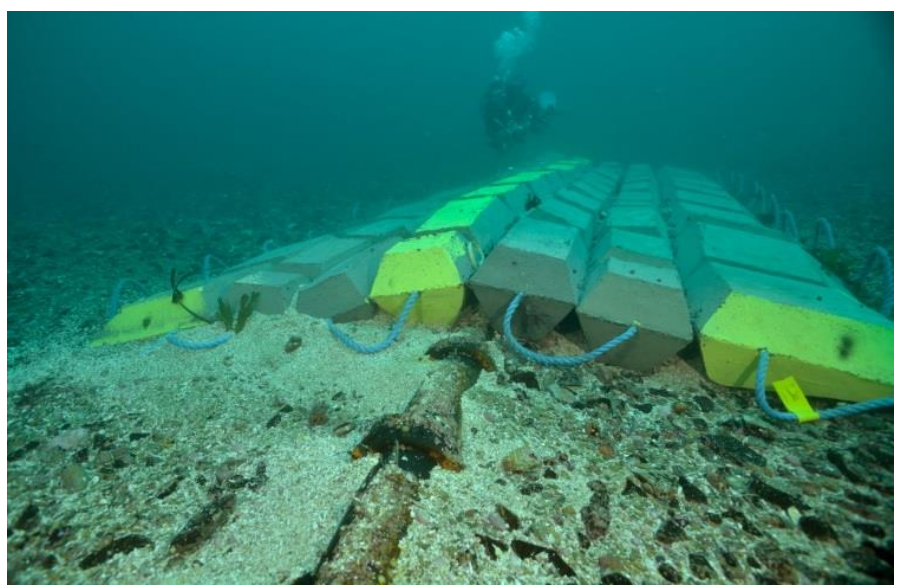

Fig 2. 


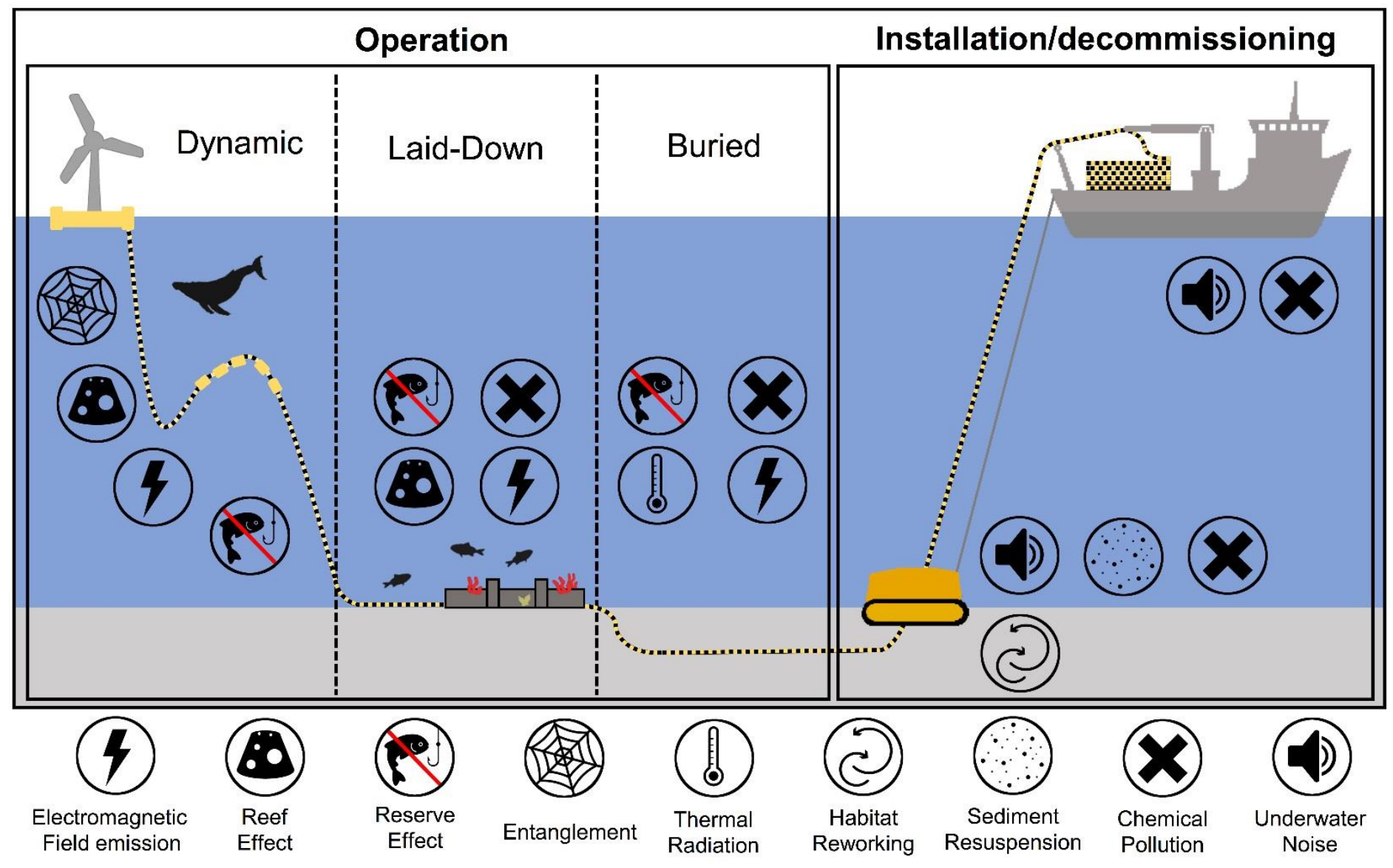

Fig 3. 


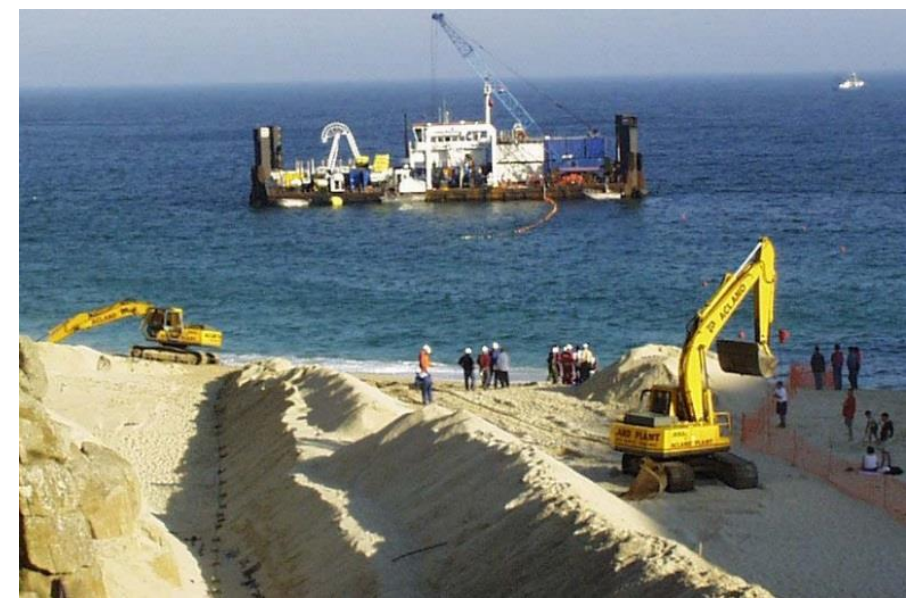

Fig 4. 

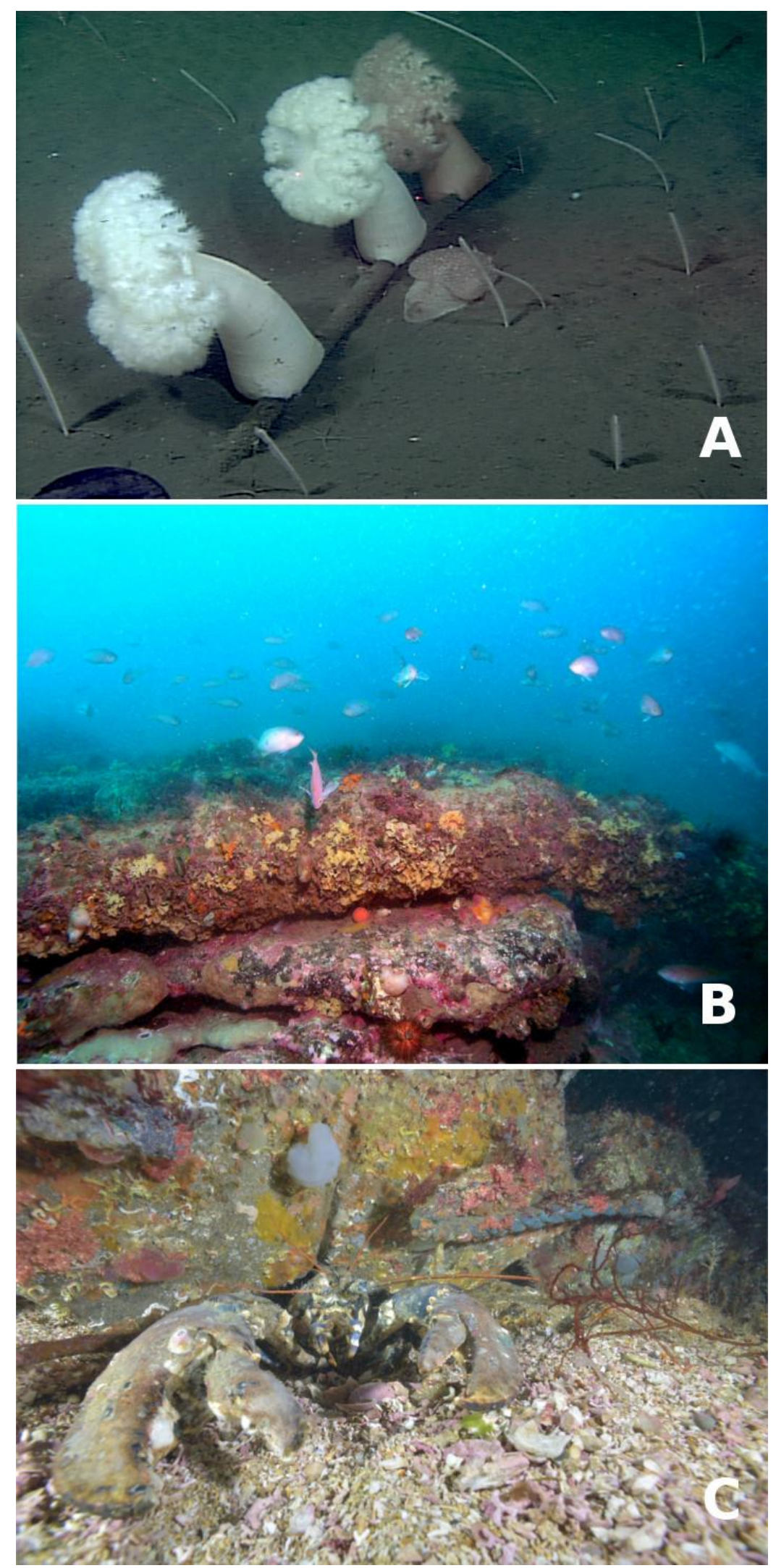

Fig 5. 


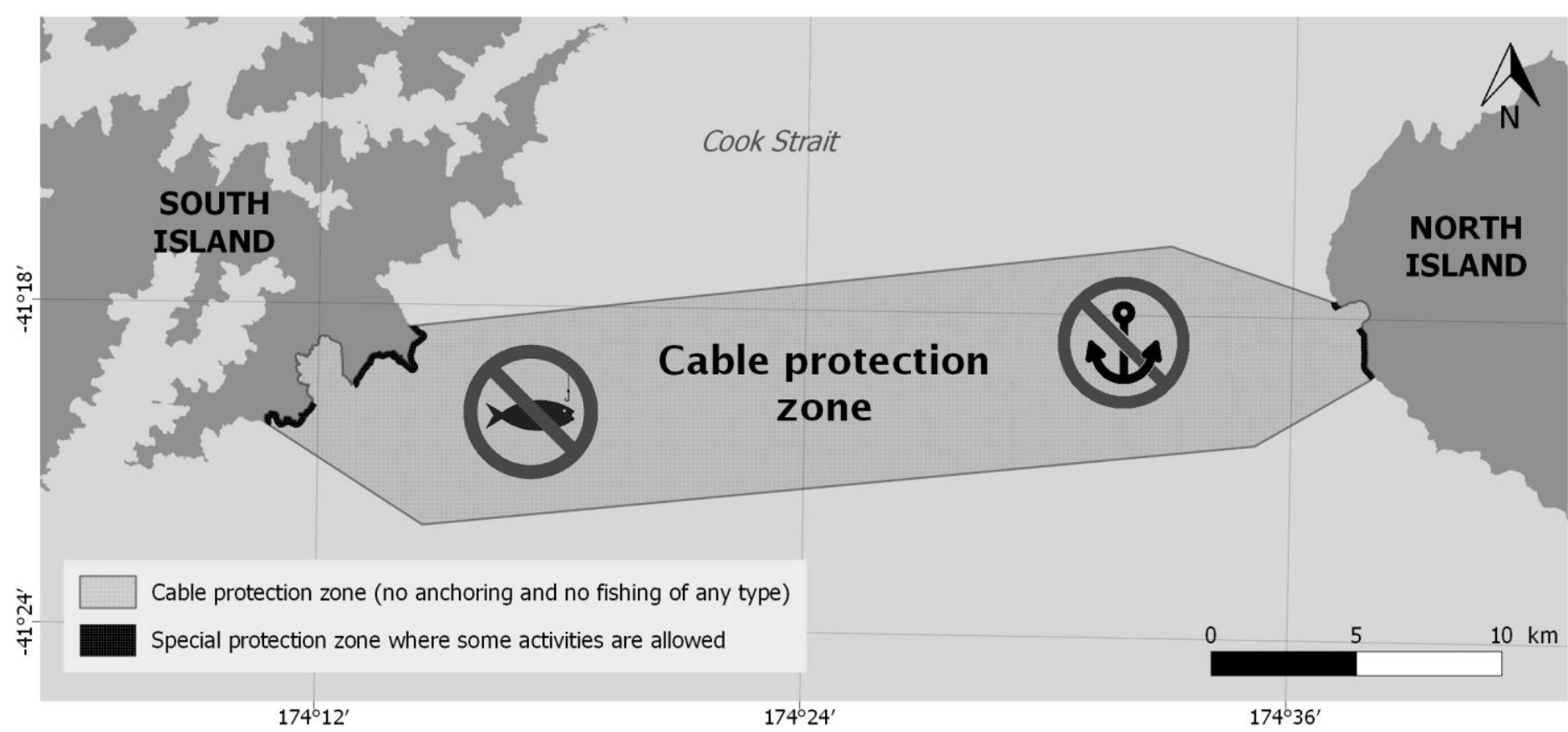

Fig 6. 

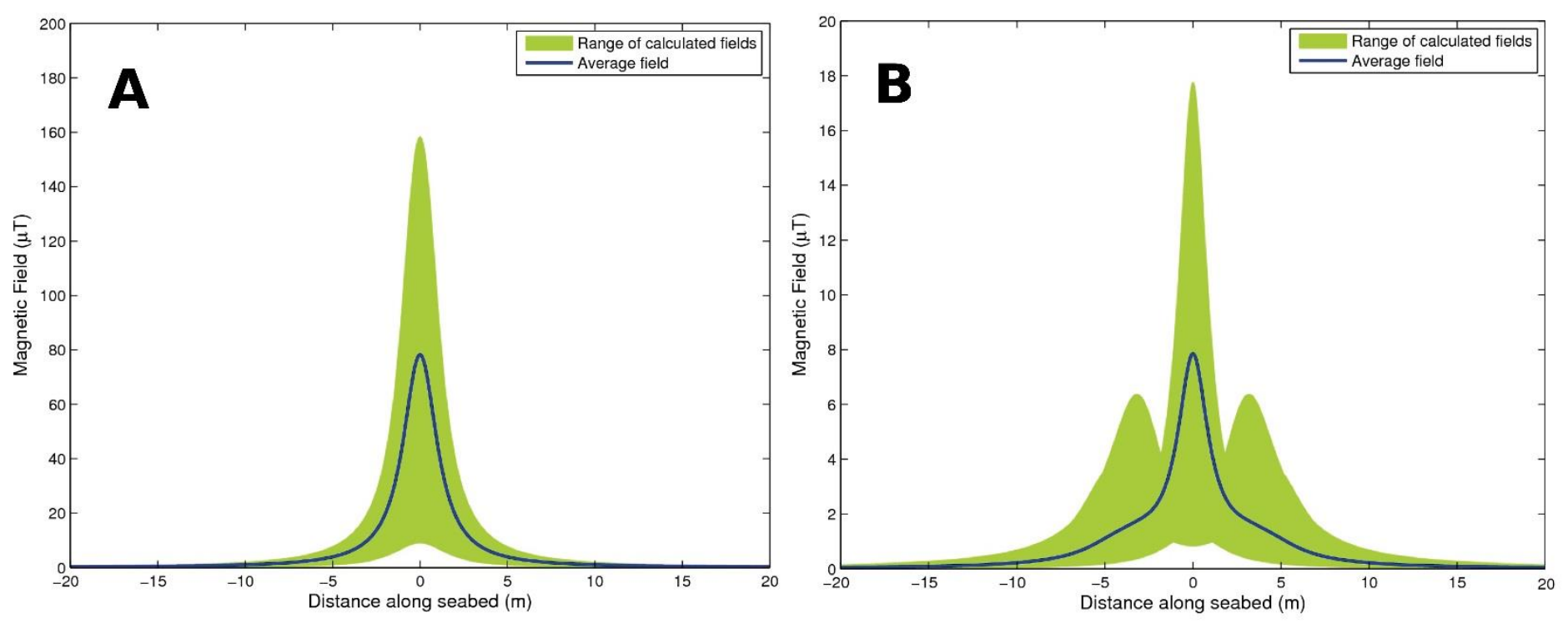

Fig 7. 

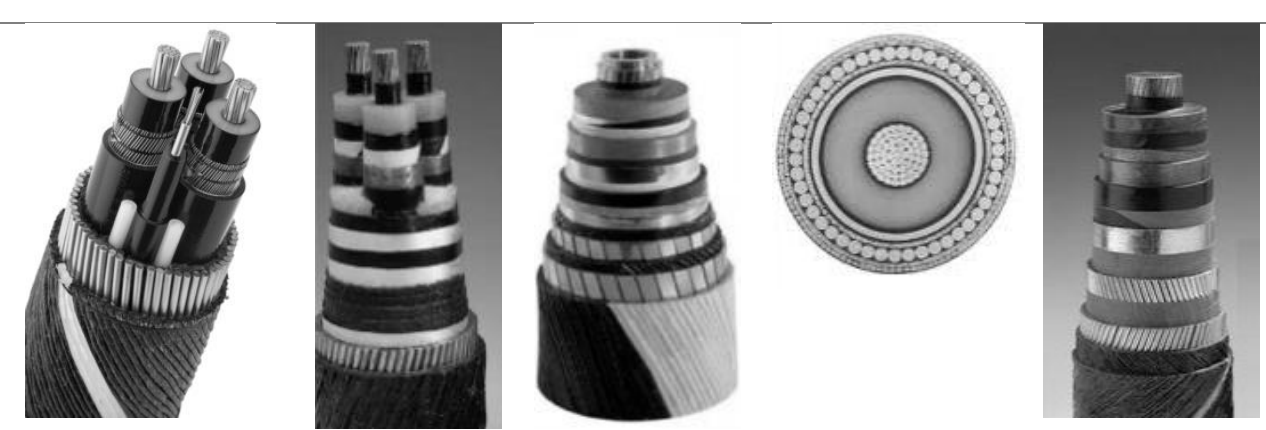

\begin{tabular}{|c|c|c|c|c|c|}
\hline Type & 1 & 2 & 3 & 4 & 5 \\
\hline $\begin{array}{c}\text { Rated } \\
\text { voltage }\end{array}$ & $33 \mathrm{kV} \mathrm{AC}$ & $150 \mathrm{kV} \mathrm{AC}$ & $420 \mathrm{kV} \mathrm{AC}$ & $320 \mathrm{kV} \mathrm{DC}$ & $450 \mathrm{kV} \mathrm{DC}$ \\
\hline Insulation & XLPE, EPR & XLPE & $\begin{array}{l}\text { Oil/paper or } \\
\text { XLPE }\end{array}$ & Extruded & $\begin{array}{c}\text { Mass- } \\
\text { impregnated }\end{array}$ \\
\hline $\begin{array}{c}\text { Typical } \\
\text { application }\end{array}$ & $\begin{array}{l}\text { Supplying small } \\
\text { islands, } \\
\text { connection of } \\
\text { offshore wind } \\
\text { turbines }\end{array}$ & $\begin{array}{l}\text { Connecting } \\
\text { islands with } \\
\text { large } \\
\text { populations, } \\
\text { offshore } \\
\text { wind parks } \\
\text { export cables }\end{array}$ & $\begin{array}{l}\text { Crossing } \\
\text { rivers/straights } \\
\text { with large } \\
\text { transmission } \\
\text { capacity }\end{array}$ & $\begin{array}{l}\text { Long distance } \\
\text { connections of } \\
\text { offshore } \\
\text { platforms or } \\
\text { wind farms }\end{array}$ & $\begin{array}{l}\text { Long distance } \\
\text { connection of } \\
\text { autonomous } \\
\text { power grids }\end{array}$ \\
\hline $\begin{array}{l}\text { Maximum } \\
\text { length }\end{array}$ & $20-30 \mathrm{~km}$ & $70-150 \mathrm{~km}$ & $<50 \mathrm{~km}$ & $>500 \mathrm{~km}$ & $>500 \mathrm{~km}$ \\
\hline $\begin{array}{l}\text { Typical } \\
\text { rating }\end{array}$ & $30 \mathrm{MW}$ & $180 \mathrm{MW}$ & $\begin{array}{l}700 \mathrm{MW} / \text { three } \\
\text { cables }\end{array}$ & $\begin{array}{c}1000 \mathrm{MW} / \text { cable } \\
\text { pair }\end{array}$ & $\begin{array}{c}600 \\
\text { MW/cable }\end{array}$ \\
\hline
\end{tabular}

Table 1. Description of five generic submarine power cable types (Photos: $1=$ General Cable; 2, 3, $4=$ Ningbo Orient Wires and Cables Co. Ltd; 5 = ABB Sweden), XLPE: Cross-Linked Polyethylene; EPR: Ethylene Propylene Rubber (reproduced from [17]). 


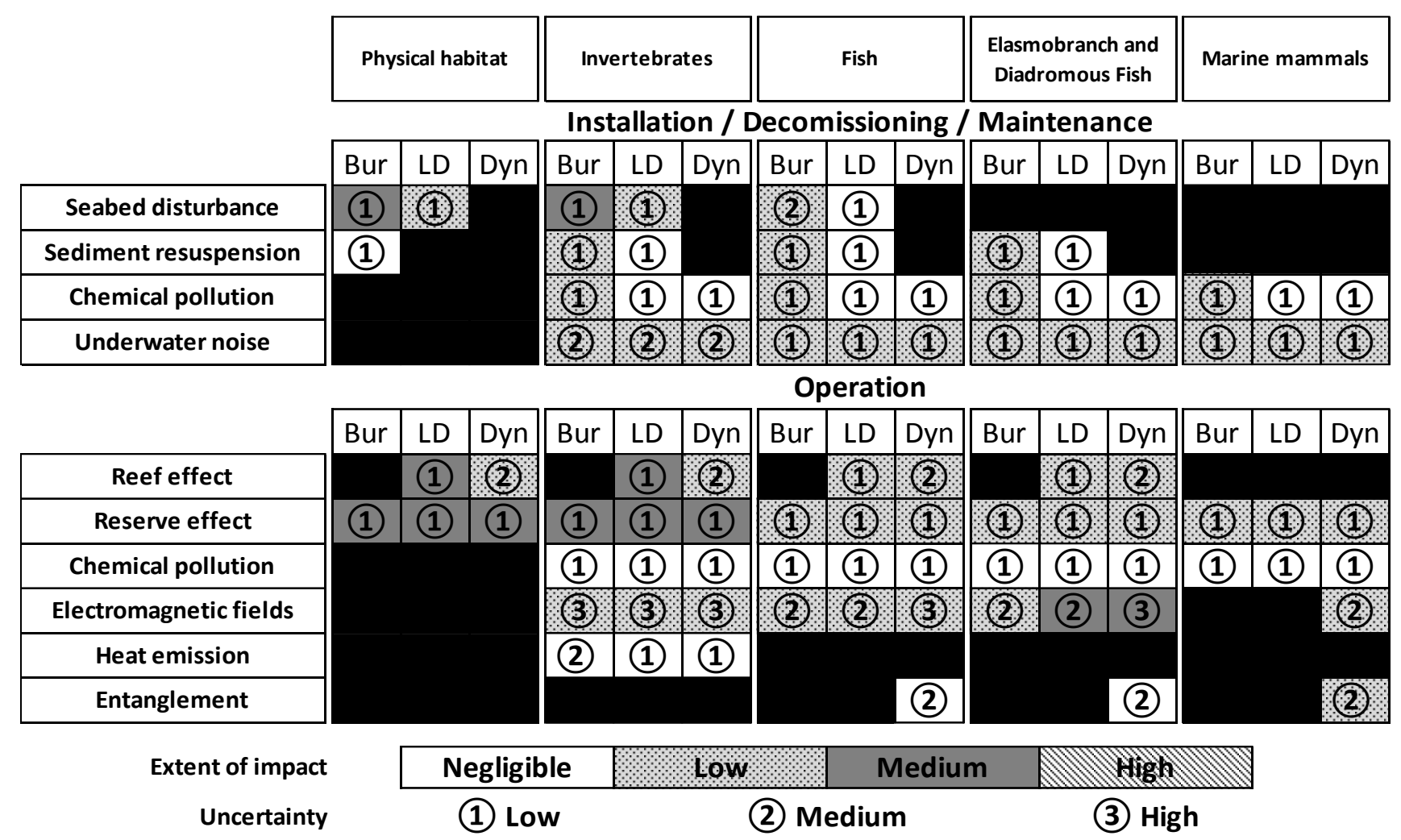

Table 2. Synthesis of the importance of potential impacts caused by Submarine Power Cables (SPC) on different marine compartments during installation, operation, maintenance and decommissioning, based on the author's interpretation of the reviewed literature. For each interaction, the extent of the impact and associated uncertainty are quantified as 'Negligible', 'Low', 'Medium' or 'High'. Bur = Buried SPC; LD $=$ Laid-Down SPC Dyn $=$ Dynamic SPC. Black fill = no impact. 